\title{
COLOUR IMPORTANCE IN VISUALIZATION OF INFORMATION
}

\section{Jitka ORAVCOVÁ}

\begin{abstract}
Colour schemes in visual materials is the factor affecting quality of recipient's perceptions, cognitive processes and will activities. Understanding psychological effects of colours is relevant when creating selfstudy materials due to their influence on motivation and quality of memorising information.
\end{abstract}

Key words: perceiving of colours, psychological meaning of colours, colour in presenting of information, objels.

\section{VÝZNAM FARIEB VO VIZUALIZOVANÍ INFORMÁCIÍ}

Resumé: Farebnost' zobrazovaných informácií je faktorom, ktorý ovplyvñuje psychiku príjemcu, kvalitu jeho preživania, kognitívne aj vôlové procesy. Poznanie psychologických účinkov farieb je významné pri tvorbe samoučiacich materiálov z hl'adiska ich vplyvu na osvojovanie si informácií, motivovanie a na vštiepenie si do pamäti.

Klúčové slová: vnimanie farby, psychologický význam farieb, farba v zobrazovaní informácie, objektov.

Úvod

Informačno-komunikačné technológie majú dnes nezastupitel'né miesto v edukačnom procese. Ich využívanie je priam nevyhnutnou súčast'ou dištančného vzdelávania, ako metódy, ktorá namiesto bezprostredného kontaktu žiaka a učitel'a zavádza sprostredkovaný kontakt, umožňujúci študujúcim učit' sa samostatne, a to vd'aka samoinštrukčným materiálom, ako sú špecifické učebnice, cvičebnice, multimediálne materiály a pod. Vytvorit' takýto učebný materiál však nie je jednoduché.

Ciel'om samoinštrukčných materiálov je nájst' taký spôsob predkladania informácií, ktorý umožní kvalitné, rozvíjajúce, motivujúce a l'ahko osvojitel'né a zapamätatel'né poznanie bez priameho riadenia učitel'om - lektorom. Jedným zo spôsobov ako takéto poznanie dosiahnut', je podávanie informácí́ $\mathrm{v}$ podobe obrazu, teda formou vizualizácie informácií, pričom najčastejšie ide o kombináciu obrazovej, textovej, resp. akustickej podoby informácie. Skúsenosti aj experimentálne skúmanie dokazujú, že pomocou názoru, obrazu si väčšina jednotlivcov osvojuje informácie rýchlejšie, lepšie a trvalejšie si ich pamätá, osvojovanie je prežívané ako príjemnejšie, l'ahšie. Obrazy dokážu sprostredkovat' viac informácií $v$ kratšom čase a sprostredkúvajú súčasne viac významových prvkov ako slová (Vysekalová; Komárková, 2002). Spracovat' informáciu do vizuálnej podoby tak, aby bola efektívna, teda aby viedla k dobrému poznaniu, predpokladá podl'a nášho názoru rešpektovat' pri vizualizácii informácií viaceré faktory, ktoré súvisia:

- s charakterom komunikácie, ktorá prebieha v situácii prijímania informácií prostredníctvom obrazu. V prípade dištančného vzdelávania, resp. v prípade učenia sa prostredníctvom IKT ide vlastne o masovú komunikáciu, ktorá sa zarad'uje k osobitým druhom komunikácie s osobitnými špecifikami komunikačného procesu,

- so zákonitost'ami fungovania psychických poznávacích (kognitívnych) procesov, ktoré sa na prijímaní informácie zúčastňujú,

- $s$ individuálnym štýlom prijímania informácií jednotlivcom - individuálnym kognitívnym štýlom a štýlom učenia sa.

Tvorba kvalitného materiálu teda vyžaduje (mimo iné) poznanie fungovania psychických procesov zúčastnených na prijímaní informácií. Pri príjme vizualizovanej informácie ako spôsobe poznávania, sa, samozrejme, účastnia všetky psychické procesy učiaceho sa, a to tak kognitívne, ako aj emocionálne a vôl'ové procesy, nakol'ko psychika človeka funguje ako celok, psychické procesy pracujú súčinne a vzájomne ovplyvňujú poznávanie, spracúvanie informácií, prežívanie aj správanie jednotlivca. Najvyšší podiel majú však procesy 
kognitívne, medzi ktoré zarad'ujeme vnímanie, pozornost', predstavivost', myslenie a pamät'. Každý z týchto procesov predstavuje osobitnú problematiku z hl'adiska jeho účasti na príjme vizualizovanej informácie. V tomto príspevku sa venujeme len jednému z procesov, t. j. vnímaniu, konkrétne vnímaniu farieb, resp., pokúsime sa poukázat' na niektoré psychologické zákonitosti vnímania farby a účinku farby na vnímanie, a tým aj poznávanie, osvojovanie si informácií.

\section{Vnímanie farby}

Vnímanie je všeobecne charakterizované ako aktívny proces poznávania sveta (vonkajšieho aj vnútorného), sprostredkovaný zmyslovými orgánmi a spracovaný $\mathrm{v}$ mozgu do podoby mentálnej reprezentácie predmetu vnímania. V jednom okamihu pritom človek vníma nielen vonkajšie prostredie, ale aj svoje vnútorné reakcie, prežívanie, pričom tieto zdroje vnímania sa prelínajú a spoločne ovplyvňujú výslednú podobu spracovanej informácie - podnetu.

Farba je v podstate pocit vyvolaný viditel'ným elektromagnetickým žiarením, ktorý závisí okrem fyzikálnych javov (spektrálneho rozdelenia vlnenia ) aj od činnosti oka a mozgu, dokonca aj od psychického prežívania. Farebný vnem je osobný zážitok, objektívne nemeratel'ný, jeho skúmaním sa zaoberá fyzika, biológia, psychológia, výtvarné umenie.

Základnými prvkami vnemov farieb (pocitov farby) sú svetlost', farebnost' odtien̆a a sýtost' farby. Ludské oko má vel'mi jemnú rozlišovaciu schopnost' na jas, ako aj na farebné odtiene, sme schopní rozlišovat' 150 - 200 odtieňov monochromatických farieb. Farebná sýtost' je stupeň odlišnosti niektorého farebného odtieňa od neutrálneho tónu rovnakej svetlosti. Vnímanie sýtosti farby závisí od stupňa jasnosti objektu. Ako najsýtejšie vidíme farby pri stredne intenzívnom osvetlení. Pri nižšom osvetlení farba tmavne a jej sýtost' klesá, tak ako aj pri vysokom stupni jasu.

Farby vo všeobecnosti rozdel'ujeme na achromatické - biela, sivá, čierna a jej odtiene - a chromatické, z ktorých základnými sú modrá, žltá, červená. Postupne bola k základným farbám (vzhl'adom $\mathrm{k}$ diferencovanosti odpovedí organizmu na farby) zaradená aj zelená, hoci vzniká miešaním modrej a žltej. Miešaním chromatických farieb vznikajú d’alšie farby farebného spektra. Človeku je, na rozdiel od mnohých zvierat, ktoré vidia len nepestré - achromatické farby (rozdiel medzi svetlým a tmavým - vraj ani býk nevidí červenú farbu, reaguje len na dráždenie pohybom látky), daná schopnost' vnímat' celé spektrum farieb Niektoré iné náhl'ady zarad’ujú k základným farbám červenú, zelenú a modrú, ktorých miešaním vzniká väčšina iných farieb.

V minulosti boli známe viaceré teórie vnímania farby, dnes, zdá sa, je preferovaná tzv. trichromatická (trojfarebná teória). Podl’a nej sietnica obsahuje tri druhy čapíkov, ktoré v závislosti od obsahu rôznych farebných látok sú citlivé na svetlo dlhej (červená), strednej (zelená) alebo krátkej (modrofialová) vlnovej dížky. Vplyvom podráždenia svetlom súbor týchto svetlocitných buniek "vymieša“ výslednú farbu, ktorú vnímame. Táto teória sa viaže $\mathrm{k}$ menám ako Young alebo Helmholtz a vychádza $z$ experimentov, ktoré začal už Newton (Atkinson, 2003).

Uvedenú hypotézu podoprel aj Youngov súčasník J. Dalton, skúmaním farbosleposti. Zistil, že to, čo väčšina l'udí vníma ako červenú farbu, je pre farboslepého jedinca len tmavá škvrna, oranžovú, žltú a zelenú farbu vnímajú farboslepí len ako odtiene žltej.

$Z$ hl'adiska využitia farby a jej účinku $\mathbf{v}$ oblasti vizualizácie informácií, resp. tvorby učiacich programov, môžeme rozlíšit' dva okruhy využitia farby:

- vplyv farebných plôch na prežívanie (emocionalitu, dynamiku) jednotlivca;

- využitie asociačného účinku farby na vyvolávanie pocitov mimo zrakového analyzátora, čo slúži k lepšej identifikácii a lepšiemu porozumeniu prvkom vizuálnej komunikácie.

\section{Vplyv farebných plôch na psychiku jednotlivca}

Farebnost' plochy (pozadia, ale aj textu, resp. časti zobrazeného materiálu) ovplyvňuje celkové vnútorné prežívanie človeka, a to najmä z hl'adiska aktivity - pasivity, vzrušenia - uvol'nenia, otvorenosti - uzavretosti k príjmu informácií, príjemnosti a nepríjemnosti vnútorných pocitov. $Z$ tohto hladiska hovoríme o psychologickom význame farieb, nakol'ko vnímanie určitej farby aktivizuje určité psychické procesy a ovplyvňuje kvalitu prežívania jednotlivca.

Psychológia rozlišuje objektívny a subjektívny význam farieb. $\mathrm{Na}$ existencii objektívneho významu farieb je založený výklad pôsobenia farby na jednotlivca a jeho 
využitie v rôznych oblastiach v psychodiagnostike, učebných materiáloch, reklame a pod. Objektívnym významom farby rozumieme skutočnost', že vnímaná každá farba vyvoláva zmyslový pocit (odraz farby vo vedomí), teda fyziologický jav a vyvoláva emocionálne prežívanie, ktoré je v prvom okamihu vnímania farby rovnaké u všetkých l'udí (farby pôsobia na vegetatívny nervový systém, ktorý nemá jednotlivec pod kontrolou a vyvolávajú prostredníctvom tohto systému stimuláciu alebo uvol'nenie). Farba je takto pocit’ovaná ako emocionálny signál, vnímanie farby prežíva človek v zlomku sekundy, skôr, ako ju môže vedome reflektovat' a definovat'. Objektívne prežívanie farby prebieha spontánne a nevedome, je nemožné ho vedome usmernit' a ovplyvnit'.

Existuje však subjektívny význam farieb, čo situáciu, samozrejme, komplikuje. Každý človek má subjektívny, osobný postoj k vnímanej farbe, niektoré farby sú mu sympatické, niektoré l'ahostajné či nepríjemné. Z tohto faktu vychádzajú psychologické testy osobnosti založené na subjektívnej preferencii určitých farieb.

Využitie vplyvu farby v prípade vizuálnej komunikácie (vizualizácie materiálu, Elearningu) sa opiera predovšetkým o objektívny význam farieb. Existenciu subjektívneho významu farieb je potrebné mat' na pamäti, ale nie je možné tento jav brat' pri tvorbe plne do úvahy, vzhl'adom na to, že vytváraný materiál je určený na použitie rôznymi jednotlivcami, ktorých vzt'ah kjednotlivým farbám nepoznáme. Napriek tomu uvádzame pri opise psychologického významu najmä základných farieb ich pozitívny aj negatívny účinok na jednotlivca, ktorý v jednotlivých prípadoch súvisí ovel'a viac so subjektívnym, individuálnym významom farby.

Psychologické významy farieb rozpracoval predovšetkým M. Lüscher (autor Testu farieb určeného na diagnostiku osobnostných vlastností, 1969). Jeho opis účinkov základných farieb zobrazuje tabul'ka 1:

\begin{tabular}{|c|c|c|c|}
\hline Farba & $\begin{array}{c}\text { Fyziolog. } \\
\text { účinok }\end{array}$ & Prežívanie & Zmysel \\
\hline červená & stimulácia & vzrušenie & aktivita \\
\hline modrá & upokojenie & pokoj & spokojnost' \\
\hline zelená & kontrakcia & napätie & pevnost' \\
\hline žltá & dilatácia & uvol'nenie & zmena \\
\hline
\end{tabular}

Tabul'ka 1: Účinok základných farieb.
V tomto pohl'ade využil M. Lüscher rozdielnost' základných farieb z hl'adiska dvoch bipolárnych dimenzií - schopnosti farby vyvolat' pocit tepla/chladu a schopnosti vyvolat' vzrušenie/uvol'nenie. M. Lüscher sa síce oprel o uvedené klasické rozdelenie farieb, ale navyše, na základe vlastných dlhodobých empirických výskumov, opísal aj podrobnejší, diferencovanejší účinok d’alších farieb a ich odtieňov na jednotlivca, v zmysle ich účinku na psychiku. Takto opísal osem farieb - červená, modrá, zelená, žltá, fialová, hnedá, čierna a sivá (in Dvořáček, 1990).

\section{ČERVENÁ FARBA}

Základný psychologický obsah farby: vitalita, aktivačná úroveň.

Červená farba je farbou vzrušenia, ktoré môže mat' pozitívnu podobu (aktivita, láska) aj negatívnu podobu (rozčúlenie, hnev, agresia). Vnímanie červenej farby vedie k stimulácii, červená farba má ergotropné účinky na vegetatívny nervový systém (vyvoláva nervovú a hormonálnu aktivitu), spôsobuje zrýchlenie, stupňovanie, stimuláciu sympatiku - pri jej vnímaní sa zrýchl'uje dych, zvyšuje sa krvný tlak a pulz. Červená farba pôsobí sprostredkovane na kostrové svalstvo v zmysle ,pohotovosti k akcii“".

V psychologickom význame červená pozitívne oslovuje takého jednotlivca, ktorý je sám silný, plný života, energický, sebavedomý. Moc ukrytá v tejto farbe oslovuje a násobí jeho moc a akcieschopnost'. Ten, kto je slabý, môže naopak pri stretnutí s červenou farbou prežívat' pocit ohrozenia.

Kladné účinky: červená aktivizuje, vyvoláva energické akcie, povzbudzuje chut' niečo podnikat', prežívat', prenikat' dopredu, menit', vyvoláva radost', prahnutie po aktivite, prežívanie pôžitku $\mathrm{z}$ aktivity, nadšenie, túžbu dobývat', získavat', dosiahnut' úspech, podporuje sebadôveru.

Negatívne účinky (ak niekto odmieta červenú farbu): vyvoláva obranný postoj proti vzrušeniu, zvýšeniu aktivity, ktoré je vnímané ako hrozba. V tomto prípade vedie k podráždenosti, pocitu pret’aženosti až hnusu, prežívaniu zlosti, oslabeniu sebadôvery, odmietaniu materiálu. V tomto kontexte sa červená spája u jednotlivca s predstavami ohňa, krvi, nebezpečenstva, hluku (čo sa spája nepochybne s individuálnymi skúsenost'ami) tento význam sa prenáša do červenej farby výstražných znamení (napr. semaforu). 
Okrem vzrušivosti pôsobí červená aj vznešene, používa sa všeobecne na vzbudenie úcty, obdivu (červené rúcha kardinálov, král'ov...). Červená súvisí vzhl'adom na stimulačné účinky so sexualitou, môže až vyvolávat' (podporovat') sexuálne vzrušenie (červené lampy nevestincov, červené osvetlenie, červená bielizeň), d’alej povzbudzuje chut' k jedlu, zvyšuje hlasitost' rozhovoru, podnecuje vznik agresívneho správania. Červená vôbec je vyjadrením rivalizačných, konfrontačných sklonov vo všetkých oblastiach l'udskej činnosti.

\section{Oranžovočervená farba}

Psychologické a fyziologické účinky červenej farby stupňuje.

\section{Oranžová farba}

Symbolika oranžovej farby je spojená s predstavou slnka, bohatej úrody, bohatstva, vyvoláva pocit radosti, slávnostného, vzrušeného očakávania. Podl’a Lüschera však môže vyvolat' také vzrušenie, ktoré má až charakter bezciel'neho, hektického rozčúlenia.

\section{Tmavočervená farba}

Je farbou pokoja, prímeria, mieru bez konfliktov. Vyvoláva prežívanie vznešenosti, je vhodná najmä vo fáze ukončovania úloh - už sme dosiahli, čo sme chceli a potrebovali. Podporuje prežívanie radosti, sebavedomia z dosiahnutého ciel'a, napája sa najmä na vnútorné prežívanie, silu. Je farbou spravodlivosti.

\section{Ružová farba}

Je kombináciou červenej a bielej farby červená aktivizuje, biela zmierňuje pudenie k akcii, vytvára väčší priestor. Ružová podporuje miernu, „nežnú“ aktivitu, je v nej zahrnutá vol'nost' a súčasne energia.

\section{Tmavomodrá farba}

Základný psychologický obsah farby: pokoj, emocionálne vzt'ahy, prežívanie.

Tmavomodrá je farbou pokoja, vyvoláva upokojenie tela a duše. Má trofotropné účinky na vegetatívny nervový systém, vyvoláva spomalenie dychu, pulzu a znižuje krvný tlak. Organizmus sa pod jej vplyvom deaktivizuje, dostáva sa do stavu relaxácie, aktivizujú sa regeneračné mechanizmy. $\mathrm{Na}$ druhej strane, v oblasti psychiky rastie citovost' a zranitel'nost'. Na fyziologickej úrovni teda vedie k utíšeniu, upokojeniu, na úrovni psychiky $\mathrm{k}$ stavu hlbšieho prežívania, $\mathrm{k}$ pocitom pokoja až $\mathrm{k}$ prežívaniu blaženosti z pokoja, mieru. Modrá farba sa viaže $\mathrm{s}$ intenzitou prežívania, empatického až medidatívneho vedomia. Nie je plne statická - nevyvoláva úplný pokoj, skôr vnútorné prežívanie, ponorenie sa do híbok.

Pozitívne účinky: modrá navodzuje stav pokoja, ktorý je predpokladom pokojného vnímania, prijímania (informácií), trpezlivého rozmýšl’ania, meditovania. Navodzuje stav vnútornej spokojnosti, vnútornej harmónie, relaxovanej senzitivity, ako nevyhnutnej podmienky empatie, oduševnenosti, estetického uchopovania a meditatívneho uvedomovania (Borbély; Obuch, 1993).

Negatívne účinky (odmietanie tmavomodrej): obrana proti pokoju, neaktivite, pokoj je preživaný ako prázdnota, ako nudný a nezaujímavý (materiál je vnímaný ako nudný), čo vedie $\mathrm{k}$ nespokojnosti, netrpezlivosti, resp. $\mathrm{k}$ depresívnemu prežívaniu. Odmietanie tmavomodrej, t. j. odmietanie pokoja, máva príčinu $\mathrm{v}$ absencii základných väzieb - vtedy sme v stave pohotovosti, nemôžeme si dovolit' pokoj, pretože hrozí rozplynutie $\mathrm{v}$ ničote.

Tmavomodrá farba môže pôsobit' vážne, smutne, môže vyvolávat' melanchóliu, je to farba dial'ok, hlbín, rozjímania, ale na druhej strane tiež farba plášt’a Panny Márie - symbolu bezpečia, harmónie, spokojnosti. Je symbolom feminity.

\section{Modrá farba}

Je l'ahšie zrozumitel'ná farba pokoja. Je symbolom pokojnej (ale nie zákerne hlbokej) vody, reprezentuje flegmatický, pokojný temperament, nehu, dôveru, lásku, oddanost'. Predstavuje tiež stálost', tradíciu (častý výber modrých polí erbov).

\section{Svetlomodrá farba}

Predstavuje bezstarostné veselie, nevyvoláva pocit nárokov, nutnost' angažovat' sa. Je l'ahká, vzdušná, vyvoláva príjemné pocity nezáväznosti, nepovinnosti, skôr romantickej túžby.

\section{Zelená farba}

Základný psychologický obsah farby: sebauplatnenie, vytrvalost', napätie.

Zelená farba pôsobí stimulačne na parasympaticus, jeho prostredníctvom na hladké svalstvo (najmä svalstvo vnútorných 
orgánov) a vyvoláva napätie. Vyvoláva fyziologický stav „elastickej tenzie“, t. j. pripravenost', pohotovost' organizmu klást' odpor. Zelená farba je zložená z modrej a žltejmodrá a žltá sú protikladné sily, ktoré sa v zelenej vzájomne rušia, takže nastáva nehybnost', pokoj, ale ich sila je utlmená len zdanlivo. Predstavujú potenciál energie, ktorý smeruje dnu alebo von podl'a farebného odtieňa zelenej.

Symbolicky je zelená spojená s prírodou, zelená je tu statická, ale je v nej obsiahnutá potencionalita rastu. Zelená sa spája s majestátnost'ou sekvoje, ktorá sa vysoko týči nad nižšími stromami, je to vysoký, pevný, vzpriamený, hrdý strom.

V oblasti psychiky sa zelená farba taktiež spája s napätím, húževnatost'ou a vytrvalost'ou, ale najskôr v zmysle postavenia hrádze, ktorá odráža, nie prepúšt’a vonkajšie podnety. Preferencia zelenej sa u jednotlivca spája s prísnym postojom, autokraciou, hrdost'ou, sebaovládaním, nadradenost’ou nad druhými, snahou kontrolovat' a riadit' dianie.

Zelená sama o sebe nemá žiadny emocionálny obsah (Borbély; Obuch, 1993), vystupuje skôr ako brzdná sila a obmedzenie voči všetkým dynamizujúcim zážitkom.

Pôsobenie zelenej farby je však silne ovplyvnené jej farebnými odtieňmi, ktoré výrazne menia psychologický význam zelenej.

\section{Modrozelená farba}

Vyvoláva pocitovo najväčší chlad, spája sa so sterilným prostredím, môže viest' $\mathrm{k}$ najväčšej uzatvorenosti proti svetu, či k vytváraniu najvýraznejšieho odstupu. Čím viac je modrej v zelenej, tým sa farba stáva chladnejšou, napätejšou, tvrdšou a odolnejšou.

\section{Žltozelená farba}

Vedie naopak k otvoreniu sa, vystúpeniu zo zajatia statickej absolútnej zelenej, dáva impulz k nadviazaniu kontaktu, záujem sa obracia navonok, vyvoláva otvorenie $\mathrm{k}$ podnetom vonkajšieho sveta.

\section{Žltá farba}

Základný psychologický obsah farby: zmena, možnost', riešenie.

Fyziologicky ovplyvňuje žltá farba sympaticus aj parasympaticuc (oba systémy vegetatívnej nervovej sústavy), pôsobí difúzne, dilatačne a vedie k uvol'neniu. Pôsobením žltej síce tiež stúpa tlak krvi, frekvencia pulzu a dychu, ale priebeh je skôr kolísavý, nie taký vyrovnaný ako pôsobením červenej.

Pozitívne účinky: žltá vytvára priestor pre slobodu, pre zmeny. Je spojená s pocit'ovaním úprimnosti plnej nádejí, otvorenosti pre nové poznatky, možnosti. Vyvoláva psychickú relaxáciu, ako uvol'nenie zo zát’aže, problémov, obmedzení, vytvára priestor pre príjem nového. Symbolizuje dynamickú pohybovú energiu, ktorá smeruje von. Žltá vzniká miešaním červenej a zelenej - spája teda vzrušenie z červenej farby a vnútorné napätie zelenej, čím vzniká vzrušené napätie, ktoré je pozitívne a má tendenciu uvol'nit' sa $\mathrm{v}$ aktivite.

Negatívne účinky: sú v podstate minimálne. Jej negatívom môže byt' to, že vyvoláva chut' do práce, aktivity, ale (v dôsledku kolísavej súčinnosti sympaticu a parasympatiku) môže spôsobovat' kolísanie pozornosti, povrchnost', kolísanie výkonu (l'udia preferujúci žltú pracujú niekedy nadšene ale s prelietavou, nenaplnenou podnikavost'ou, chýba vytrvalost'). Odmietanie žltej, teda negatívneho prežívania, sa spája so strachom zo zmeny, straty istoty.

Symbolicky sa žltá spája so slnkom, ktoré je dynamom uvol'ňujúcej sa energie, šíriacej sa von. Žltá symbolizuje základnú l’udskú potrebu rozvíjat' sa, je v nej nádej, túžba po radosti a rozkoši (symbolizuje tiež uvol'nenie, ktoré nastáva bezprostrednej po orgazme). Žltá farba oslobodzuje, povzbudzuje, pôsobí veselo a otvorene.

\section{Fialová farba}

Základný psychologický obsah farby: identifikácia, senzibilita, fascinácia.

Fialová farba je zmesou modrej a červenej, spája v sebe impulzívnost', vzrušivost' červenej a pokoj modrej farby. Podl'a niektorých autorov je spojením mužského (červená) a ženského princípu (modrá) a je vyjadrením splynutia, zjednotenia protikladov, prelínania objektívneho a subjektívneho, ale na druhej strane tiež farbou pohlavnej nevyhranenosti (podl'a Lüschera fialovú preferujú deti pred pubertou, homosexuáli a tehotné ženy).

Fialová farba vo svojich protikladoch vyjadruje snahu dosiahnut' ciele bojovnou dobyvačnost'ou a súčasne oddávaním sa a dávaním sa. Vyjadruje potrebu splynutia vibrujúcej senzibility a spirituálnej túžby. Fialová sa ostatne stala symbolom mystiky.

Pozitívne účinky: fialová farba vyvoláva emócie očarenia, prežívanie záhadnosti, tajuplnosti, vzbudzuje očakávanie, fascinuje 
a vyvoláva zvedavost'. Môže vyvolat' celý rad pocitov - od zmyslovej vzrušenosti, erotickej fascinácie až po spirituálne nadšenie.

Negatívne účinky: odmietanie fialovej farby a jej negatívne prežívanie sa môže spájat' s obavou pred ovplyvnením, fascinovaním, manipuláciou inými alebo sobavou pred odkrytím vlastného vnútra, vlastných túžob. Fialová farba sa však tiež spája s neistotou, kolísavost'ou, emocionálnou labilitou, únikom do nereálneho sveta prianí a magicky splnených predstáv. Môže vyvolávat' neaktivitu, melancholické prežívanie.

\section{Hnedá farba}

Základný psychologický obsah farby: telesnost', pudovost', bezpečnost'.

Hnedá je kombináciou tmavej žltej a červenej farby. Vitalita červenej je stlmená, redukovaná. Stupeň vzrušivosti je znížený na minimum, hnedá reprezentuje stav blahodarnej pohody. Pocit'ovanie hnedej farby sa spája s vitálnymi, zmyslovými pocitmi, vyvoláva pocit pohody, bezpečia, istoty, poriadku, pokoja (biologického, telesného uspokojenia), vracia človeka na zem. Symbolicky sa spája s farbou a teplom zeme, teplom domova, istotou, bezpečím, zakorenením, istotou intimity

\section{Sivá farba}

Základný psychologický obsah farby: angažovanost', autentickost', sociálna začlenenost'. Sivá farba je neutrálna, nepestrá, achromatická, čo platí najmä o strednej sivej farbe. Nie je v nej vzrušenie ani uvol'nenie, nesmeruje von ani dnu. Je reprezentantom neutrality, v psychologickom význame nie je farebným priestorom, ale hranicou medzi priestormi.

Sivá farba vyvoláva (ak vôbec stimuluje nejaké emócie) skôr smútok, nudu, pokoru alebo chudobu. Môže vyvolávat' negatívne prežívanie $\mathrm{v}$ podobe odporu, protestu proti vzbudzovaniu pocitov nudy, neangažovanosti.

\section{Čierna farba}

Základný psychologický obsah farby: protest, deštrukcia, vzt’ah $\mathrm{k}$ absolútnu.

Čierna farba znamená koniec, koniec podnetom, vzruchom, vyvoláva pocit, že to, čo je prezentované, je konečné, definitívne platné, nediskutabilné, obmedzujúce, ohraničujúce.

Čierna môže vyvolávat' nelúbost', vzdor, odmietnutie definitívnej platnosti predloženého. Čierna sa symbolicky spája so smrt'ou, ale je aj demonštráciou odporu, vzdoru - napr. v podobe čierneho oblečenia mladej generácie.

Prehl'ad psychologických charakteristík jednotlivých farieb uvádzame v tabul'ke 2 .

\begin{tabular}{|c|c|c|c|c|}
\hline \multirow{2}{*}{ Farba } & $\begin{array}{c}\text { Formálne } \\
\text { vymedzenie }\end{array}$ & $\begin{array}{c}\text { Základná } \\
\text { charakteristika }\end{array}$ & Tematizácia & \multirow{2}{*}{ Ciel' } \\
\hline & $\begin{array}{c}\text { Emočné } \\
\text { vyladenie }\end{array}$ & $\begin{array}{l}\text { Psychologická } \\
\text { potreba }\end{array}$ & $\begin{array}{c}\text { Adaptačná } \\
\text { technika }\end{array}$ & \\
\hline \multirow{2}{*}{ Modrá } & $\begin{array}{l}\text { koncentrická } \\
\text { heteronómia }\end{array}$ & $\begin{array}{l}\text { híbka prežívania, resp. } \\
\text { intenzívny cit }\end{array}$ & $\begin{array}{c}\text { naplnenie hlbokým, } \\
\text { vnútorným a harmonickým } \\
\text { cit. vzt'ahom }\end{array}$ & \multirow[b]{2}{*}{ naplnit'sa } \\
\hline & upokojenie & $\begin{array}{l}\text { pokoja a mieru, resp. } \\
\text { hlbokého cit. naplnenia } \\
\text { a vzájomnosti }\end{array}$ & $\begin{array}{c}\text { pokojné, mierne } \\
\text { a ohl'aduplné konanie, } \\
\text { pokojnost' }\end{array}$ & \\
\hline \multirow{2}{*}{ Zelená } & $\begin{array}{l}\text { koncentrická } \\
\text { autonómia }\end{array}$ & $\begin{array}{l}\text { vytrvalost', resp. pružnost' } \\
\text { vôle }\end{array}$ & $\begin{array}{c}\text { sebarealizácia, sebaúcta, } \\
\text { potvrdenie }\end{array}$ & \multirow{2}{*}{ podržat' } \\
\hline & napätie & $\begin{array}{l}\text { podržat', vlastnit', resp. } \\
\text { získat' uznanie }\end{array}$ & $\begin{array}{c}\text { vytrvalé a ciel'avedomé } \\
\text { konanie, autoritatívna stálost' }\end{array}$ & \\
\hline \multirow[t]{2}{*}{ Červená } & $\begin{array}{l}\text { excentrrická } \\
\text { autonómia }\end{array}$ & vitalita, resp. sila vôle & $\begin{array}{c}\text { účinne pôsobit', utvárat' } \\
\text { vonk. prostr. resp. prežit' } \\
\text { život intenzívne }\end{array}$ & \multirow[t]{2}{*}{ zapríčinit' } \\
\hline & vzrušenie & $\begin{array}{l}\text { spôsobit', vyvolat' resp. } \\
\text { intenzívne prežit' }\end{array}$ & $\begin{array}{l}\text { aktívne a angažované } \\
\text { konania, priebojnost' }\end{array}$ & \\
\hline \multirow{2}{*}{ Žltá } & $\begin{array}{l}\text { extentrická } \\
\text { heteronómia }\end{array}$ & spontaneita & $\begin{array}{l}\text { otvorenost' a očakávanie, } \\
\text { rozš́renie horizontu, } \\
\text { expanzia do nových oblastí }\end{array}$ & \multirow{2}{*}{ rozšírit’ sa } \\
\hline & uvol'nenie & zmeny a nového & $\begin{array}{l}\text { bezprostredné, spontánne } \\
\text { konanie, resp. nestálost' }\end{array}$ & \\
\hline
\end{tabular}




\begin{tabular}{|c|c|c|c|c|}
\hline \multirow[b]{2}{*}{ Fialová } & & vnímavost'. senzitivita & $\begin{array}{c}\text { magicko-erotické splynutie, } \\
\text { resp. fascinácia }\end{array}$ & \multirow{2}{*}{ splynút' } \\
\hline & $\begin{array}{l}\text { nediferencova- } \\
\text { nost', kolísavost' }\end{array}$ & identifikácie & $\begin{array}{c}\text { sugestibilita, závislost', resp. } \\
\text { prežívajúci prístup } \\
\text { k interakcii } \\
\end{array}$ & \\
\hline \multirow{2}{*}{ Hnedá } & & zmyslovost', telesnost' & $\begin{array}{l}\text { zmyslovo, telesne skúsit', } \\
\text { resp. zakotvit', zabývat' sa }\end{array}$ & \multirow{2}{*}{$\begin{array}{l}\text { zmyslovo } \\
\text { zakúsit' }\end{array}$} \\
\hline & l'úbost' & $\begin{array}{c}\text { pôžitku a rozkoše, resp. } \\
\text { istoty a stability }\end{array}$ & $\begin{array}{c}\text { hedonizmus, resp. regresia } \\
\mathrm{k} \text { telesnosti }\end{array}$ & \\
\hline \multirow[b]{2}{*}{ Čierna } & & protest, odvrátenie sa & $\begin{array}{c}\text { vzt'ah k absolútnu, autorite, } \\
\text { osudu, smrti }\end{array}$ & \multirow{2}{*}{ rozbit' } \\
\hline & nel'úbost' & agresie, resp. deštrukcie & $\begin{array}{c}\text { negativizmus, revolta, resp. } \\
\text { značne akcentovaná } \\
\text { adaptačná technika }\end{array}$ & \\
\hline \multirow{2}{*}{ Sivá } & & sociálna začlenenost' & $\begin{array}{c}\text { zahalit' sa, vnútorne } \\
\text { neparticipovat' }\end{array}$ & \multirow{2}{*}{$\begin{array}{l}\text { zastriet' } \\
\text { a nevysta- } \\
\text { vovat' sa }\end{array}$} \\
\hline & l'ahostajnost' & $\begin{array}{l}\text { ochrany, resp. protektívneho } \\
\text { ochraňovania }\end{array}$ & $\begin{array}{l}\text { neangažovat' sa, sociálna } \\
\text { zdržanlivost', stát' bokom }\end{array}$ & \\
\hline
\end{tabular}

Tabul'ka 2: Prehl'ad psychologických charakteristík farieb (Zdroj: Borbély; Obuch, 1993).

Aplikácie poznatkov o psychologickom význame farieb na vizualizáciu materiálu:

Domnievame sa, že z uvedeného opisu účinku farby na psychiku, si čitatel' l'ahko odvodí príslušné aplikácie na vizualizáciu pozadia, plochy či obsahu.

Podl'a M. Hardošovej a E. Malej (2003) je napr.:

- žltá farba vhodná ako farba pozadia, pretože vyvoláva uvol'nenie, relaxáciu, otvorenost', v kombinácii so svetlo-zelenou pôsobí osviežujúco, aktivizujúco, príjemne,

- oranžová, ktorá vyvoláva pocit radosti, je vhodná na úvodné aktivity,

- červená je vhodná na upútanie pozornosti, zvýšenie koncentrácie, zdôraznenie významu (vhodná pre kontrolné úlohy, cvičenia, evalváciu),

- tmavočervená je autorkami odporúčaná na zdôraznenie významu materiálu,

- naopak, fialová farba nie je vhodná ako farba pozadia, pretože môže vyvolat' nepokoj, melanchóliu, rozpoltenost'.

My môžeme pridat' vlastné úvahy:

- zelená, osobitne modrozelená farba (s výrazným podielom zelenej) nie je vhodná na prezentáciu nových informácií (vyvoláva uzatváranie sa, odpor k novému, snahu zachovat' pôvodné postoje),

- ostro červená farba u viacerých vyvoláva odpor, hnus, je príliš vzrušujúca,

- privel'a modrej farby deaktivuje príjemcu, vyvoláva nudu podobne ako farba sivá,
- čierna farba je základnou, bežne používanou farbou písma, odporúča sa (najmä zvýraznená - „tučná“) na uvedenie definícií - hotových nediskutovatel'ných poznatkov a záverov,

- tmavočervená, resp. hnedá farba je vhodná pre záverečné časti materiálu, ukončovanie úloh,

- ružová farba vedie k príjemnej aktivizácii, povzbudzuje kaktivite nenásilným spôsobom,

- tmavomodrá farba je vhodná pre úlohy, ktoré vyžadujú premýšl’anie, meditáciu.

\section{Využitie farby na kvalitnejšie zobrazenie} prvkov vizuálnej komunikácie

Využitie farieb pri vizualizácii obsahov nie je, ako sme už uviedli, viazané len na farebné plochy (napr. pozadie textu, obrázka), čím sa usilujeme vyvolat' prežívanie adekvátne obsahu, povzbudzujúce motiváciu a pod., ale týka sa aj farebného zobrazenia objektov v zmysle podpory ich vlastností či charakteristík.

Značí to, že nie je l'ahostajné, akú farebnost' určitých konkrétnych obrazov zvolíme. Je síce možné volit' fantastickú, nereálnu farebnost' konkrétnych prvkov (napr. fialová tráva či ružový slon), v tom prípade však musí mat' táto vol'ba konkrétny ciel'. Vo všeobecnosti platí, že pri osvojovaní informácií zo zobrazeného materiálu je vhodné skôr reálne zobrazenie objektov, ked' farba pomáha dotvorit' informáciu o tomto objekte. 
V tomto smere vychádza farebné zobrazovanie z poznatkov o asociáciách, ktoré farby vyvolávajú $\mathrm{v}$ predstavách jednotlivca. Tieto asociácie majú jednak všeobecne platný

charakter, jednak, podl'a Behrensa (in: Vysekalová; Komárková, 2002, s.142), existujú špeciálne asociácie spojené s objektom, ako uvádza tabul'ka 3:

\begin{tabular}{|c|c|c|}
\hline Farby & Všeobecné asociácie & Asociácie spojené s objektom \\
\hline Červená & $\begin{array}{l}\text { aktívna, podnecujúca, veselá, vládnúca, } \\
\text { vzrušujúca }\end{array}$ & horúca, hlasná, plná, silná, sladká, pevná \\
\hline Oranžová & $\begin{array}{l}\text { srdečná, žiarivá, živá, priatel'ská, jasná, } \\
\text { veselá, vzrušujúca }\end{array}$ & teplá, sýta, blízka, podnecujúca, suchá, krehká \\
\hline Žltá & $\begin{array}{l}\text { svetlá, jasná, vol’ná, pohyblivá, } \\
\text { dynamická, otvorená }\end{array}$ & vel'mi l’ahká, hladká, kyslá, obt’ažná \\
\hline Zelená & $\begin{array}{l}\text { upokojujúca, osviežujúca, pokojná, } \\
\text { farba nádeje }\end{array}$ & $\begin{array}{c}\text { chladná, št’avnatá, vlhká, kyslá, svieža, jedovatá, } \\
\text { mladá }\end{array}$ \\
\hline Modrá & pasívna, zdržanlivá, istá, pokojná & $\begin{array}{l}\text { studená, mokrá, silná, lesklá, vel'ká, hlboká, } \\
\text { vzdialená, tichá, plná }\end{array}$ \\
\hline Fialová & $\begin{array}{l}\text { vážna, pochmúrna, nešt'astná, ponurá, } \\
\text { pološerá, znepokojujúca }\end{array}$ & zamatová, narkotická, sladká, mäkká, mystická \\
\hline
\end{tabular}

Tabul'ka 3: Asociácie farieb Zdroj: Vysekalová-Komárková, 2002.

$\mathrm{Na}$ presnejší príjem informácií je možné využit' tiež jav zvaný synestézie, t. j. obrazy, ktoré vznikajú spojením pocitu v jednom zmyslovom analyzátore (napr. zrakovom) s predstavou $\mathrm{v}$ inom zmyslovom analyzátore, na ktorý $\mathrm{v}$ danom okamihu žiadny podnet nepôsobí.
Videnie farby teda vyvoláva zrakové pocit'ovanie (pocit farby) a súčasne aktivuje predstavu v iných, najmä dotykových a chut'ových receptoroch. Aké konkrétne kvality predstáv pocitov $\mathrm{v}$ iných zmysloch vyvolávajú základné farby ukazuje tabul'ka 4 .

\begin{tabular}{|c|c|c|c|c|c|}
\hline & Žltá & Zelená & Modrá & Červená & Ružová \\
\hline $\begin{array}{l}\text { Pocit } \\
\text { tiaže }\end{array}$ & $\begin{array}{l}\text { „l'ahká“, čím je } \\
\text { svetlejšia, tým } \\
\text { „l'ahšie“" pôsobí }\end{array}$ & $\begin{array}{c}\text { premenlivá } \\
\text { podl'a } \\
\text { odtieňa, } \\
\text { (vid' modrá) }\end{array}$ & $\begin{array}{l}\text { premenlivá } \\
\text { podl'a odtieňa, } \\
\text { čím svetlejšia, } \\
\text { tým l'ahšia }\end{array}$ & $\begin{array}{c}\text { premenlivá podl’a } \\
\text { odtieňa }\end{array}$ & „l'ahká“ \\
\hline $\begin{array}{c}\text { Pocit } \\
\text { dotyku }\end{array}$ & $\begin{array}{l}\text { „mäkká“ } \\
\text { predovšetkým } \\
\text { v kombinácii } \\
\text { s červenou }\end{array}$ & neutrálny & $\begin{array}{c}\text { svetlomodrá: } \\
\text { „mäkká““; } \\
\text { tmavomodrá: } \\
\text { „drsná“, ,,hrubá““ }\end{array}$ & $\begin{array}{c}\text { nie vel'mi výrazná, } \\
\text { tmavočervená: } \\
\text { „skôr drsná“ }\end{array}$ & $\begin{array}{l}\text { „nežná“, } \\
\text { „vel'mi } \\
\text { mäkká“‘ } \\
\text { (napr. } \\
\text { dojčenská } \\
\text { bielizeň) }\end{array}$ \\
\hline $\begin{array}{l}\text { Pocit } \\
\text { chuti }\end{array}$ & $\begin{array}{l}\text { „sladká“, pokial' } \\
\text { prechádza do } \\
\text { červenej a svetlej; } \\
\text { „horká“, pokial” } \\
\text { prechádza do zelenej }\end{array}$ & $\begin{array}{l}\text { „horkác“, } \\
\text { „slanác“ }\end{array}$ & takmer neutrálna & $\begin{array}{l}\text { „korenistá“, } \\
\text { „pálivá““, } \\
\text { „chrumkavá‘, } \\
\text { pokial' prechádza } \\
\text { do hnedej } \\
\end{array}$ & „sladkastá“ \\
\hline $\begin{array}{l}\text { Pocit } \\
\text { tepla }\end{array}$ & $\begin{array}{l}\text { „teplác, „horúca“, } \\
\text { pokial' prechádza do } \\
\text { červenej; čím } \\
\text { svetlejšia, tým } \\
\text { „chladnejšia“ }\end{array}$ & $\begin{array}{l}\text { „chladno } \\
\text { svieža“" }\end{array}$ & $\begin{array}{c}\text { „chladná““, } \\
\text { „svieža“; } \\
\text { svetlomodrá: } \\
\text { „vel'mi studená“ }\end{array}$ & „teplá“ až „horúca & $\begin{array}{l}\text { „telesná } \\
\text { teplota“" }\end{array}$ \\
\hline
\end{tabular}

Tabul'ka 4: Synestézie pocitov viazaných s pocitom farby Zdroj: Vysekalová; Komárková, 2002.

Farby sú takto na základe ich schopnosti vyvolávat' asociáciami pocity pri vizualizácii objektov použitel'né na priblíženie zobrazovaných predmetov realite, na ich lepšiu, adekvátnejšiu identifikáciu v súlade so zámerom materiálu a môžu tak slúžit' na adekvátnejšie porozumenie prekladaným obrazom a obsahu materiálu. 
Príklad aplikácie poznatkov na zobrazenie prvkov:

- postava oblečená vodeve svetlých farieb (svetlomodrá, biela, ružová) vyjadrujúca gestikuláciou agresiu je menej reálna a užívatel' možno neuverí či neporozumie agresii obrazu tak dobre, ako keby táto postava bola oblečená $\mathrm{v}$ červenom,

- kávu v šálke je nutné vyjadrit' hnedou, tekutinu v pohári, na ktorej si pochutnáva nakreslená osoba, nemožno vyjadrit' žltozelenou, pretože táto farba vyvoláva pocit horkej, kyslej, nepríjemnej chuti,

- o čiernej lodi na modrom mori nikto neuverí, že je to lod', ktorá letí rýchlost'ou blesku,

- žlté lôžko v cele väzňa vyvolá predstavu príjemného, „mäkkého“ spočinutia a nie tvrdých podmienok pre trestaného,

- ostro zelené jablko nemôže vyvolat' predstavu jeho sladkej, lahodnej chuti,

- tmavomodré hory nebudú vnímané ako d'aleké, ale ako blízke a pod.

\section{Záver}

V príspevku sme sa pokúsili poukázat' na niektoré súvislosti využitia farieb a zákonitostí ich vnímania pri zobrazovaní informácií a objektov v samoučiacich materiáloch, využívaných $\mathrm{v}$ dištačných formách štúdia. Poznanie týchto zákonitostí, pôsobenia farby na psychiku učiaceho sa, považujeme za dôležité východisko pre tvorbu materiálov, ktorých ciel'om je dosiahnut' samostatné a pritom kvalitné osvojenie si poznatkov.

\section{Literatúra}

(1) ATKINSON, R. Psychologie. Praha: Portál. 2003. ISBN 80-7178-640-3.

(2) BORBÉLY, L.; Obuch, I. Praktický manuál k použivaniu Lüscherovho farebného testu. Nové zámky: AZ Print. 1993. ISBN 80-8872902-5.

(3) DVOŘÁČEK, V. 1990. Lüscherưv barvový test. Brno: SPS. 1990.

(4) HARDOŠOVÁ, M.; MALÁ, E. Využitie audio-vizuálnych prvkov pri tvorbe dištančného jazykového kurzu. In: Zborník príspevkov $z$ konferencie E-learn 2003. Ostrava: 2003. s. 175-179.

(5) LÜSCHER, M. The Lüscher Color test. New York: Washington Squer Press. 1969.

(6) VYSEKALOVÁ, J.; KOMÁRKOVÁ, R. Psychologie reklamy. Praha: Grada. 2002. ISBN 80-247-0402-1.

Doc. PhDr. Jitka Oravcová, PhD.

Katedra psychológie PF

UMB Banská Bystrica

E-mail: joravcova@pdf.umb.sk 